\title{
Susceptibility of Three Rose Genotypes to Japanese Beetle (Coleoptera: Scarabaeidae) Adult Feeding
}

\author{
Paul Thomas Tiddens and Raymond A. Cloyd
}

\begin{abstract}
Japanese beetle (Popillia japonica) adults are a major insect pest of cultivated roses, causing extensive feeding damage to both foliage and flowers. Insecticides are primarily used to minimize adult injury to roses; however, insecticides may be harmful to natural enemies and their use may be restricted, particularly in public gardens. An alternative management strategy is the use of rose genotypes that express some level of herbivore tolerance. However, there is little information on rose genotypes that are tolerant or less susceptible to adult Japanese beetle leaf feeding. This study evaluated the susceptibility of three new rose genotypes introduced into the Crasberg Rose Garden at the Chicago Botanic Garden, Glencoe, Illinois, U.S. The genotypes were Rosa 'Radrazz' Knock Out ${ }^{\mathrm{TM}}$, Rosa 'Crimson Bouquet,' and Rosa 'Love and Peace.' Two laboratory experiments, a no-choice and multiple-choice leaf-feeding assay, were conducted in 2002 and 2003 to assess susceptibility of the new rose and two established genotypes to Japanese beetle adult feeding. Although there were significant statistical differences between the rose genotypes, in almost all cases the mean percentage damage rating exceeded 50\%. Mean percentage damage ratings for the 2002 and 2003 no-choice experiments ranged from 15\% to 78\% and $60 \%$ to $75 \%$, respectively. Mean percentage damage ratings for the 2002 and 2003 multiple-choice experiments ranged from $34 \%$ to $58 \%$ and $47 \%$ to $53 \%$, respectively. These results indicate that all the rose genotypes tested are susceptible to Japanese beetle adult feeding and may not be appropriate selections for use in areas with established Japanese beetle populations.
\end{abstract}

Key Words. Host plant resistance; integrated pest management; Japanese beetle; plant health; Popillia japonica; Rosa spp.

Japanese beetle, Popillia japonica Newman (Coleoptera: Scarabaeidae), was first discovered in the United States in 1916 in New Jersey (Dickerson and Weis 1918; Johnson and Lyon 1991). As early as 1939 it was predicted that Japanese beetle populations would spread throughout the country and become permanently established (Fox 1939). Japanese beetles are now found in almost every state east of the Mississippi River (Daar et al. 1996). Of the nearly 300 species of plants fed upon by Japanese beetle, roses appear to be the most preferred woody host (Hawley and Metzger 1940; Fleming 1972). Japanese beetle adults are major insect pests of cultivated roses grown in the eastern and midwestern portions of the United States (Johnson and Lyon 1991).

The Chicago Botanic Garden (Glencoe, IL) contains the Crasberg Rose Garden, which has one of the largest rose collections in the United States. The garden displays over 5,000 roses and is updated periodically to showcase roses, including All-American Rose Selection award winners (AARS) (Chicago Botanic Garden 2004). Within the past 13 years, the Japanese beetle has become permanently established at the Chicago Botanic Garden (Tiddens 2004). As a result, many rose genotypes favored by Japanese beetles are not being incorporated into landscapes in northeastern Illinois. The primary means of minimizing Japanese beetle adult feeding on roses is the use of insecticides (Potter and Held
2002). Although insecticide use may be justified to maintain the aesthetic quality of roses displayed in botanic gardens, a goal of the Chicago Botanic Garden's Integrated Pest Management (IPM) program is to maintain plant quality with minimum insecticide use. There are also concerns regarding the impact of broad-spectrum insecticides on beneficial organisms (Van Driesche and Bellows 1996). To minimize insecticide use, selecting roses that exhibit tolerance or that are less susceptible to Japanese beetle feeding could be a method to reduce insecticide inputs in the permanent collections. In fact, plant resistance or tolerance offers the greatest promise for low-input sustainable management of Japanese beetle adults (Potter and Held 2002). There is significant variability in susceptibility to Japanese beetle feeding among birch, Betula spp. (Ranney and Walgenbach 1992), flowering crabapple, Malus spp. (Ranney and Walgenbach 1992; Potter et al. 1998), linden, Tilia spp. (Miller and Ware 1999), and elm, Ulmus spp. (Miller et al. 1999). However, no resistance has been discovered in roses (Potter et al. 1998). Held and Potter (2004) note that prior to their study in determining the floral characteristics that attract Japanese beetle adults, research on roses and susceptibility to Japanese beetle adult feeding was limited, with only one previously published study investigating resistance of roses to adult Japanese beetle (Potter et al. 1998). 
The purpose of this study was to evaluate how susceptible three new rose genotypes, Rosa 'Radrazz' Knock Out ${ }^{\mathrm{TM}}$, Rosa 'Crimson Bouquet,' and Rosa 'Love and Peace,' are to Japanese beetle adult leaf feeding under laboratory conditions.

\section{MATERIALS AND METHODS}

To assess the susceptibility of the three new rose genotypes to Japanese beetle adult feeding, two experiments were conducted: a no-choice experiment and a multiple-choice experiment. The experiments were conducted in July 2002 and 2003 at the Chicago Botanic Garden between 1100 and 1900 degree days $\left(\mathrm{DD}_{10^{\circ} \mathrm{C}}\right)$, when adult Japanese beetle populations are active (Figure 1).

\section{Plant Material}

Rosa 'Radrazz' Knock Out (Knock Out rose), Rosa 'Crimson Bouquet' (Crimson Bouquet rose), and Rosa 'Love and Peace' (Love and Peace rose) were selected because they are the most recent rose genotypes introduced into the Crasberg Rose Garden permanent collection (planted in 2001), as well as AARS award winners. Two additional rose genotypes that are commonly used in landscapes in the Chicagoland area and are planted extensively in the Crasberg Rose Garden were also evaluated: Rosa 'Centifolia' (Cabbage rose) and Rosa 'Nearly Wild' (Nearly Wild rose). Cabbage rose was selected due to its apparent susceptibility to Japanese beetle adult feeding based on previous history in the Crasberg Rose Garden, whereas Nearly Wild rose was selected because it appears to be less susceptible to Japanese beetle adult feeding (T. Tiddens, pers. obs.).

\section{Japanese Beetle Collection}

Adult Japanese beetles, used for both experiments, were collected using four Trece Catch Cans (Trece Inc., Adair, OK)

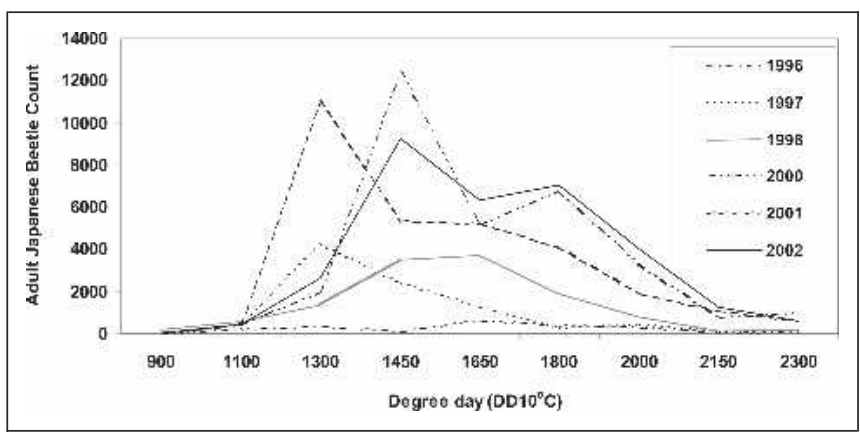

Figure 1. Japanese beetle, Popillia japonica (Newman) adult counts based on degree days $\left(\mathrm{DD}_{10^{\circ} \mathrm{C}}\right)$ at the Chicago Botanic Garden (Glencoe, IL) from 1996 through 2002. Adult counts obtained using four Trece Catch Can Traps (Trece Incorporated, Adair, OK) located throughout the Chicago Botanic Garden. Traps were baited with Trece 3-Way Lure (Trece Incorporated, Adair, OK). Data not available for 1999. baited with Trece Japanese Beetle 3-Way Lure (Trece Inc.). Collected beetles were removed from the Trece Catch Can 24 $\mathrm{hr}$ before use in the experiments and placed into a Ziploc 0.9 L (0.23 gal) clear plastic storage container (S.C. Johnson, Racine, WI) without food to standardize beetle hunger before use in the experiments. The storage container lid had 25, 1.3 $\mathrm{cm}(0.5 \mathrm{in})$ sections cut to provide ventilation. The holding container with the adult beetles was held in the laboratory at $24^{\circ} \mathrm{C} \pm 3^{\circ} \mathrm{C}\left(75^{\circ} \mathrm{F} \pm 3^{\circ} \mathrm{F}\right)$ and located $1.5 \mathrm{~m}(5 \mathrm{ft})$ below four, $34 \mathrm{~W}$ fluorescent lamps (Sylvania, Danvers, MA) for $24 \mathrm{hr}$. One hr before use, groups of five (for the no-choice experiment with a single leaflet per replication) or 25 (for the multiple-choice experiment with five leaflets per replication) active beetles were selected from the holding container and placed into a $0.9 \mathrm{~L}(0.23 \mathrm{gal})$ clear plastic storage container. Within $1 \mathrm{hr}$, those beetles were placed into an evaluation chamber.

The number of beetles per chamber to be used in the nochoice and multiple-choice experiments was determined in a preliminary study conducted several weeks before the main experiments. The selected number of adult beetles was chosen so that leaf area consumption over $24 \mathrm{hr}$ would not exceed $90 \%$ of available leaf tissue.

\section{Evaluation Chambers}

Ten evaluation chambers were created by modifying standard $18.9 \mathrm{~L}$ (4.9 gal) HDPE, $0.07 \mathrm{~mL}(0.002 \mathrm{oz})$, white plastic containers (Leaktite Corp., Leominster, MA). Each evaluation chamber had five equidistant $1.3 \mathrm{~cm}(0.5 \mathrm{in})$ diameter holes drilled in the bottom to support $10.2 \mathrm{~cm}$ (4.1 in) floral water picks (Amlings Flowerland, Hinsdale, IL), which were used to hold the prepared rose leaflets. The water picks were inserted into the holes, flush with the bottom of the container. The no-choice experiment required the use of a single water pick, whereas in the multiple-choice experiment all five water picks were used. Four empty (no leaflet or water) water picks blocked the other holes in the no-choice experiment. Each evaluation chamber was placed on a standard brick, which was used as a pedestal to allow the water picks to extrude through the bottom of the evaluation chamber. Flexible Silver Grey Fiberglass Insect Screening (Phifer Wire Products, Tuscaloosa, AL) was cut into $40.6 \times 40.6 \mathrm{~cm}(15.9 \times 15.9$ in $)$ squares to cover the top of the chamber, which was then secured using an elastic band. The chambers were centered $30.5 \mathrm{~cm}$ (12.2 in) below two, $34 \mathrm{~W}, 1.2 \mathrm{~m}$ (4 ft) fluorescent lamps (Sylvania). The temperature was maintained at $29^{\circ} \mathrm{C} \pm 3^{\circ} \mathrm{C}\left(84^{\circ} \mathrm{F}\right.$ $\pm 3^{\circ} \mathrm{F}$ ). Each experiment was conducted over a $24 \mathrm{hr}$ period under constant illumination. The evaluation chambers were washed with soap, rinsed, and allowed to dry prior to reuse.

\section{No-Choice Experiment}

Recently matured, pinnately compound rose leaves of each rose genotype were collected from the Crasberg Rose Garden in the late morning $30 \mathrm{~min}$ prior to use. Rose plants, from 
which leaflets were collected, had not been treated with any pesticides during the previous 4 weeks. The four side leaflets were excised from the petiole, leaving only the terminal leaflet. Each petiole was approximately $6.3 \mathrm{~cm}$ (2.5 in) long, and each terminal leaflet was approximately $5.1 \mathrm{~cm}(2 \mathrm{in})$ long and $2.5 \mathrm{~cm}(1 \mathrm{in})$ wide. Immediately after preparation, the petiole of each leaflet was placed into a water pick filled with deionized water, which was then placed individually into an evaluation chamber. Five adult Japanese beetles were released into the center of the evaluation chamber. After $24 \mathrm{hr}$, leaflets were removed and the petiole was excised. Each leaflet was then pressed between five pages of newspaper, weighted, and allowed to dry for at least 2 weeks. The experiment was set up as a randomized complete block design conducted over five consecutive days with two replications per rose genotype conducted each day. There were a total of ten replications per rose genotype, resulting in 50 dried leaflets to be evaluated.

\section{Multiple-Choice Experiment}

Rose leaflets for this experiment were prepared as previously described. One prepared leaflet of each of the five rose genotypes was inserted into a floral water pick and placed into one of the holes in the bottom of an evaluation chamber with the leaflets arranged equidistant from each other. Twenty-five adult beetles were released in the center of the evaluation chamber equidistant from each leaflet. After $24 \mathrm{hr}$, leaflets were removed and handled as described previously. The experiment was set up as a randomized complete block design conducted over four consecutive days with 40 replications per rose genotype, yielding 200 dried leaflets for evaluation.

\section{Percentage Leaf Damage and Data Analysis}

Each pressed and dried leaflet from the no-choice and multiple-choice experiments was mounted into a photographic album (Style No. LM-100D, Pioneer Photo Album Inc., Chatsworth, CA) with Fast-Stick ${ }^{\circledR}$ on a white $22 \times 30 \mathrm{~cm}$ $(8.0 \times 12.0$ in $)$ page with two leaflets per page. Each leaflet was assigned an identification number between 1 and 50 . Ten observers evaluated each leaflet for both the 2002 and 2003 albums and assigned an estimated feeding damage rating (\%) based on missing leaf tissue. The range was $0 \%$ to $100 \%$, including all whole numbers in between (i.e., $51 \%$ or $73 \%$ ).

The percentage feeding damage rating data were normalized by arcsine square-root transformation and subjected to a one-way analysis of variance (ANOVA) (SAS 2001), with rose genotype as the main effect. Significant treatment means were separated using a Tukey test. Nontransformed data are presented.

\section{RESULTS}

\section{No-Choice Experiment}

For 2002, rose genotype was highly significant for the percentage of Japanese beetle adult feeding damage ( $F=12.84$; $d f=4,49 ; P<0.0001)$ based on missing leaf tissue; Nearly Wild had the highest percentage damage rating (77.4\%), whereas Knock Out had a significantly lower percentage damage rating (15.1\%) (Table 1). In contrast to Knock Out, the other two new rose genotypes, Crimson Bouquet and Love and Peace, experienced more than 50\% Japanese beetle adult feeding damage (Table 1).

The percentage of Japanese beetle adult feeding damage for rose genotype was not significant for the 2003 no-choice experiment $(F=1.28 ; d f=4,49 ; P=0.29)$. All five rose genotypes experienced more than $60 \%$ Japanese beetle adult feeding (Table 1). Nearly Wild, as in the 2002 experiment, exhibited the highest percentage damage rating $(74.5 \%)$ compared to the other rose genotypes.

\section{Multiple-Choice Experiment}

For 2002, rose genotype was highly significant for the percentage of Japanese beetle adult feeding damage $(F=7.98$; $d f=4,199 ; P<0.0001$ ) based on missing leaf tissue, with all three new rose genotypes experiencing a significantly lower percentage of adult Japanese beetle feeding damage $(<50 \%$ missing leaf tissue) than the two established rose genotypes (Table 2). All three new rose genotypes experienced less than $50 \%$ adult feeding damage, whereas the established roses, Cabbage and Nearly Wild, experienced more than 50\% adult feeding damage (Table 2).

The percentage of Japanese beetle adult feeding damage for rose genotype was not significant for the 2003 multiplechoice experiment $(F=1.77 ; d f=4,199 ; P=0.13)$. Cabbage rose exhibited the highest percentage Japanese beetle damage rating (64.4\%) (Table 2). All rose genotypes experienced more than $50 \%$ adult feeding damage, with the exception of Crimson Bouquet (Table 2).

\section{DISCUSSION}

Japanese beetle adults fed extensively on all five rose genotypes tested in this study. Although there were statistically significant differences among the rose genotypes, the overall

\section{Table 1. Mean ( \pm SE) percentage leaf damage, based on missing leaf tissue, by Japanese beetle, Popillia japonica (Newman), adults for each rose genotype in the 2002 and 2003 no-choice experiments with ten replications per rose genotype.}

\begin{tabular}{llll}
\hline Rose genotype & $n$ & $2002($ mean \pm SE) & $2003($ mean \pm SE) \\
\hline Nearly Wild & 10 & $77.4 \pm 1.36 \mathrm{a}^{*}$ & $74.5 \pm 3.29 \mathrm{a}^{*}$ \\
Cabbage & 10 & $58.9 \pm 11.81 \mathrm{ab}$ & $63.0 \pm 9.57 \mathrm{a}$ \\
Crimson Bouquet & 10 & $60.5 \pm 3.17 \mathrm{~b}$ & $61.8 \pm 5.36 \mathrm{a}$ \\
Love and Peace & 10 & $50.8 \pm 4.42 \mathrm{~b}$ & $60.6 \pm 2.73 \mathrm{a}$ \\
Knock Out & 10 & $15.0 \pm 5.11 \mathrm{c}$ & $69.6 \pm 2.73 \mathrm{a}$
\end{tabular}

*Means within a column not followed by a common letter are significantly different $(P=0.05)$ as determined by a Tukey's mean separation test. 
Table 2. Mean $( \pm S E)$ percentage leaf damage, based on missing leaf tissue, by Japanese beetle, Popillia japonica (Newman), adults for each rose genotype in the 2002 and 2003 multiple-choice experiments with $\mathbf{4 0}$ replications per rose genotype.

\begin{tabular}{llll}
\hline Rose genotype & $n$ & $2002($ mean \pm SE) & $2003($ mean \pm SE) \\
\hline Nearly Wild & 40 & $57.2 \pm 5.69 \mathrm{a}^{*}$ & $52.4 \pm 5.89 \mathrm{a}$ \\
Cabbage & 40 & $52.7 \pm 4.61 \mathrm{a}$ & $64.4 \pm 4.78 \mathrm{a}$ \\
Crimson Bouquet & 40 & $34.6 \pm 3.19 \mathrm{~b}$ & $47.8 \pm 4.69 \mathrm{a}$ \\
Love and Peace & 40 & $34.8 \pm 3.67 \mathrm{~b}$ & $52.1 \pm 5.59 \mathrm{a}$ \\
Knock Out & 40 & $40.2 \pm 3.72 \mathrm{~b}$ & $51.0 \pm 4.49 \mathrm{a}$ \\
\hline
\end{tabular}

* Means within a column not followed by a common letter are significantly different $(P=0.05)$ as determined by a Tukey's mean separation test.

percentage of mean leaf damage exceeded $50 \%$ for most of the rose genotypes. The Cabbage and Nearly Wild roses, chosen for comparison, appeared to be more susceptible than the three new rose genotypes (Knock Out, Crimson Bouquet, and Love and Peace) based on overall mean percentage feeding damage ratings (Tables 1 and 2).

In the 2002 no-choice experiment, Knock Out experienced significantly less beetle damage, with an average rating of $15 \%$, whereas all the other rose genotypes tested had percentage feeding damage ratings of more than $50 \%$. Of the ten replications for the 2002 no-choice experiment, five were not fed upon, whereas the other five leaflets were fed upon extensively. It was determined that a number of Japanese beetle adults used in the Knock Out treatment were either lethargic or dead after $24 \mathrm{hr}$. However, this occurred only in this one instance. The 2003 no-choice experiment better represented the susceptibility of Knock Out, in which the percentage feeding damage rating $(69.8 \%)$ was similar to the other rose genotypes. In addition, the percentage feeding damage ratings for Knock Out in the 2002 and 2003 multiple-choice experiments were $40.2 \%$ and $51.0 \%$, respectively. Knock Out rose has been reported to be resistant to plant-feeding insects (McCoy 2004). However, in our study it was just as susceptible to Japanese beetle adult feeding as the other rose genotypes tested. Field studies need to be conducted to substantiate this claim and determine whether laboratory effects influence susceptibility.

The no-choice experiments evaluated how susceptible the rose genotypes were when exposed to five adult Japanese beetles under laboratory conditions. Based on the results from both experiments, all of the rose genotypes experienced feeding damage ratings between $50 \%$ and $78 \%$. This indicates that all five are highly susceptible to adult Japanese beetle leaf feeding when no other food source is available.

In the multiple-choice experiment, the rose genotypes Knock Out, Crimson Bouquet, and Love and Peace experienced less feeding damage than the others (Table 2). However, there was still considerable feeding damage, ranging from $34 \%$ to $65 \%$. Crimson Bouquet had the least amount of feeding damage, followed by Love and Peace and then Knock Out (Table 2). Although all five rose genotypes are susceptible to Japanese beetle feeding, the three new rose genotypes experienced less feeding damage. It is possible that the use of 25 adult beetles per chamber may have created crowded conditions that affected feeding preference. However, under natural infestations, Japanese beetle adults tend to congregate in large masses (Smith and Hadley 1926; Hawley and Metzger 1940), which increases the amount of plant damage. In addition, the $24 \mathrm{hr}$ test period, which is typically used to conduct feeding preference studies, may have compromised the ability of the study to detect real differences in susceptibility because Japanese beetle adults are mobile and likely to leave a nonfavorable food source under field conditions.

The use of observers to evaluate insect feeding damage is not uncommon: similar research assessing Japanese beetle adult feeding damage has been conducted using observer estimates (Ranney and Walgenbach 1992; Fulcher et al. 1998; Miller and Ware 1999). In our study, ten observers were used per leaf sample and the results were consistent across both the no-choice and multiple-choice experiments in the degree of variability, indicating there was no observer effect. Observer assessments, which are an accessible and simple measurement method, may be useful to home gardeners or landscape professionals who have an interest in measuring plant injury but would not have access to tools such as leaf area meters.

This laboratory study suggests that the five cultivated roses tested are highly susceptible to Japanese beetle adult feeding. Our study is in agreement with Potter et al. (1998) in that most roses are going to be susceptible to Japanese beetle feeding to some degree. Potter et al. (1998) field-screened 53 rose genotypes during a summer when Japanese beetle populations were high and found that all were heavily defoliated. The study was repeated the following summer when Japanese beetle populations were low, and Potter et al. (1998) found considerable variation in damage. Although some rose genotypes may exhibit some degree of resistance or tolerance, when Japanese beetle populations are high, most roses are likely to experience considerable plant damage, which will substantially reduce aesthetic quality.

Other factors that can influence the level of susceptibility to Japanese beetle adult feeding include the amount of sunlight received and flower color (Held and Potter 2004). It was predicted that the Nearly Wild rose would not be favored by adult Japanese beetles in the study because of the low level of feeding damage observed in the field, which seemed to indicate possible resistance or tolerance in the Crasberg Rose Garden (T. Tiddens, pers. obs.). The Crasberg Rose Garden planting of Nearly Wild roses is in a densely shaded area underneath large trees. Japanese beetles prefer to feed on roses located in full sun (Johnson and Lyon 1991), whereas roses located in wooded areas are seldom attacked (Daar et al. 1996). However, in both the no-choice and multiple-choice 
laboratory experiments, the leaves of Nearly Wild were fed upon extensively ( $52 \%$ to $78 \%$ feeding damage) by Japanese beetle adults. Field studies need to be conducted to assess the validity that Japanese beetle adults feed less on roses grown in shade.

Held and Potter (2004) determined that white and yellow rose flowers attract more Japanese beetle adults than the darker colors such as apricot, orange, pink, mauve, and red. Nearly Wild rose has a dark pink flower, which may be less preferred by Japanese beetle adults. In contrast, Cabbage rose has a history of being favored by Japanese beetles in the Crasberg Rose Garden (T. Tiddens, personal observation). Plantings of Cabbage rose are located in full sun for approximately $8 \mathrm{hr}$ per day, and the flowers are predominantly white with slight pink coloration, which supports the findings of Held and Potter (2004). Additionally, Cabbage rose does not flower continuously; its peak flowering period coincides with peak adult Japanese beetle emergence at the Chicago Botanic Garden, thus increasing susceptibility to adult beetle feeding, which leads to this rose suffering more damage. Studies have also shown that leaves that have been fed upon by Japanese beetle adults produce induced volatile compounds that are attractive to additional adult Japanese beetles (Loughrin et al. 1995). For Cabbage rose, the combination of flower color, flowering time, and beetle aggregation may explain why this rose is so susceptible to Japanese beetle adult feeding in the Crasberg Rose Garden. Additional factors not tested in this study such as rose height, fragrance, flower size, petal count, and number of blooms may also affect rose susceptibility to Japanese beetle adults (Held and Potter 2004).

In conclusion, the five rose genotypes evaluated were all susceptible to adult Japanese beetle leaf feeding. Results from the no-choice and multiple-choice experiments indicate that these rose genotypes may not be suitable selections for the Crasberg Rose Garden and Chicagoland area, and possibly other areas of Illinois. Although all were substantially fed upon in the no-choice and multiple-choice experiments, there was variation in susceptibility, suggesting they may harbor some level of resistance or tolerance. In landscape settings, a mild level of resistance or tolerance could be magnified by appropriate placement or grouping to reduce susceptibility to adult Japanese beetle feeding.

\section{LITERATURE CITED}

Chicago Botanic Garden. 2004. Available at www. chicagobotanic.org/Images/explore/rose/RoseGuide.pdf (accessed 12/6/04).

Daar, W., H. Olkowski, and W. Olkowski. 1996. CommonSense Pest Control. Taunton Press, Newtown, CT, pp. 83 and 534.

Dickerson, E.L., and H.B. Weis. 1918. Popillia japonica Newman, a recently introduced pest. Canadian Entomology 50:217-221.
Fleming, W.F. 1972. Biology of the Japanese Beetle. U.S. Department of Agriculture Technical Bulletin 1449.

Fox, H. 1939. The probable future distribution of the Japanese beetle in North America. Journal of the New York Entomology Society 47:105-123.

Fulcher, F.F., T.G. Ranney, J.D. Burton, J.F. Walgenbach, and D.A. Danehower. 1998. Role of foliar phenolics in host plant resistance of Malus taxa to adult Japanese beetles. HortScience 33(5):862-865.

Hawley, I.M., and F.W. Metzger. 1940. Feeding Habits of the Adult Japanese Beetle. U.S. Department of Agriculture Circular 547.

Held, D.W., and D.A. Potter. 2004. Floral characteristics affect susceptibility of hybrid tea roses, Rosa $\times$ hybrida, to Japanese beetles (Coleoptera: Scarabaeidae). Journal of Economic Entomology 97(2):353-360.

Johnson, W.T., and H.H. Lyon. 1991. Insects That Feed on Trees and Shrubs, 2nd ed. Comstock Publishing, Ithaca, NY.

Loughrin, J.H., D.A. Potter, and T.R. Hamilton-Kemp. 1995. Volatile compounds induced by herbivory act as aggregation kairomones for Japanese beetle (Popillia japonica Newman). Journal of Chemical Ecology 21(10): 1457-1467.

McCoy, S. 2004. Shady ladies. American Nursery 199(10): 34-36.

Miller, F., and G. Ware. 1999. Feeding preference for selected Tilia spp., and cultivars by the adult Japanese beetle (Coleopteran: Scarabaeidae). Journal of Arboriculture 25(3):168-174.

Miller, F., S. Jerdan, and G. Ware. 1999. Feeding preference of adult Japanese beetle (Coleopteran: Scarabaeidae) for Asian elm species and their hybrids. Journal of Economic Entomology 92:421-426.

Potter, D.A., P.G. Spicer, D.W. Held, and R.E. McNiel. 1998. Relative susceptibility of cultivars of flowering crabapples, lindens, and roses to defoliation by Japanese beetles. Journal of Environmental Horticulture 16: $105-110$.

Potter, D.A., and D.W. Held. 2002. Biology and management of the Japanese beetle. Annual Review of Entomology 47:175-205.

Ranney, T.G., and J.F. Walgenbach. 1992. Feeding preference of Japanese beetles for taxa of birch, cherry and crabapple. Journal of Environmental Horticulture 10(3): 177-180.

SAS. 2001. SAS System for Windows, version 8.02. SAS Institute, Inc., Cary, N.C.

Smith, L.B., and C.H. Hadley. 1926. The Japanese Beetle. U.S. Department of Agriculture Circular 363.

Tiddens, T.P. 2004. Susceptibility of Rosa 'Radrazz' Knock Out $^{\mathrm{TM}}$, Rosa 'Crimson Bouquet,' and Rosa 'Love and Peace' to Japanese beetle, Popillia japonica Newman 
(Coleoptera: Scarabaeidae) adult feeding. M.S. Thesis, University of Illinois, Urbana-Champaign.

Van Driesche, R., and T. Bellows. 1996. Biological Control. Chapman \& Hall, New York, NY.

\section{Paul Thomas Tiddens \\ Graduate Student \\ University of Illinois at Urbana-Champaign \\ Department of Natural Resources and Environmental Sciences \\ 1101 West Peabody Drive \\ Urbana, IL 61801, U.S. \\ Current address is the Chicago Botanic Garden, Glencoe, IL, U.S.}

\author{
Raymond A. Cloyd (corresponding author) \\ Associate Professor \\ University of Illinois at Urbana-Champaign \\ Department of Natural Resources and Environmental \\ Sciences \\ 1101 West Peabody Drive \\ Urbana, IL 61801, U.S. \\ rcloyd@uiuc.edu
}

Résumé. Les scarabées japonais, Popillia japonica, adultes constituent des parasites majeurs chez les rosiers cultivés car ils causent des dommages importants, à la fois sur les fleurs et les feuilles lors de leur alimentation. Les insecticides sont principalement utilisés pour minimiser les dommages causés aux rosiers par les adultes; cependant, les insecticides peuvent s'avérer dommageables pour les ennemis naturels et leur emploi peut être restreint, particulièrement dans les jardins publics. Une alternative stratégique de gestion peut être l'emploi de génotypes de roses qui expriment un certain degré de tolérance aux herbivores. Néanmoins, il y a peu d'informations disponibles sur les génotypes de roses qui sont tolérants ou moins susceptibles aux dommages causés par les scarabées japonais adultes. Cette étude évalue le degré de susceptibilité de trois nouveaux génotypes de roses introduits au Jardin de roses de Crasberg du Jardin botanique de Chicago à Glencoe en Illinois. Les génotypes étaient Rosa 'Radrazz' Knock Out ${ }^{\mathrm{TM}}$, Rosa 'Crimson Bouquet' et Rosa 'Love and Peace'. Deux expériences en laboratoire, une à essais sans choix et une à essais à choix multiples d'alimentation foliaire, ont été menées en 2002 et 2003 pour évaluer la susceptibilité des nouvelles roses ainsi que de deux génotypes déjà connus, et ce par rapport à l'alimentation des scarabées japonais adultes. Même s'il y avait des différences statistiquement significatives entre les génotypes de roses, dans la plupart des cas le pourcentage moyen de dommages excédait $50 \%$. Les pourcentages moyens de dommages lors des expériences sans choix variaient de 15 à $78 \%$ et de 60 à 75\%, et ce lors des expériences de 2002 et 2003 respectivement. Les pourcentages moyens de dommages lors des expériences à choix multiples variaient de 34 à $58 \%$ et de 47 à $53 \%$, et ce lors des expériences de 2002 et 2003 respectivement. Ces résultats indiquent que tous les génotypes de roses testés sont susceptibles au scarabée japonais adulte et qu'ils ne seraient donc pas des sélections appropriées pour être utilisées dans des endroits où les populations de scarabée japonais sont déjà établies.

Zusammenfassung. Die ausgewachsenen Japan-Käfer sind eine bedeutende Plage auf kultivierten Rosen und verursachen ausgedehnte Schäden bei Blättern und Blüten. Insektizide werden hauptsächlich eingesetzt, um die Schäden der ausgewachsenen Käfer auf Rosen zu minimieren. Aber die Insektizide können auch für andere Feinde schädlich sein, daher sollte ihr Einsatz besonders in öffentlichen Gärten eingeschränkt werden. Eine alternative Kontrollstrategie ist die Verwendung von Rosen-Genotypen, die einigermaßen Toleranz gegenüber Herbivoren zeigen. Dennoch gibt es nur wenig Information über Rosen-Genotypen, die tolerant oder weniger anfällig gegenüber Fraßschäden durch Japan-Käfer sind. Diese Studie bewertet die Anfälligkeit von drei neuen Genotypen, die in den Botanischen Garten von Chicago, Crasberg Rose Garden, eingeführt wurden. Die Genotypen waren Rosa 'Radrazz' Knock Out TM, Rosa 'Crimson Bouquet', und Rosa 'Love and Peace.' Zwei Laborexperimente, ein No-choice und ein multiple-choice Fütterungsversuch wurde in 2002 und 2003 durchgeführt, um die Anfälligkeit der neuen Rose und zwei Genotypen zu testen. Obwohl es signifikante statistische Unterschiede zwischen den Genotypen gibt, gilt doch für alle Fälle, dass die durchschnittliche Schadensrate 50\% erreicht. Die durchschnittlichen Schadensraten für 2002 und 2003 im no-choice-Experiment reichten von 15 bis 78 \& und $60 \mathrm{zu} 75 \%$ respektive. Die durchschnittlichen Schadensraten im multiplechoice-Experiment reichten von 34 bis $58 \%$ und 47 bis $53 \%$ respektive. Diese Ergebnisse zeigen, dass alle getesteten RosenGenotypen anfällig für Japan-Käfer sind und dass es nicht angemessen ist, diese Auswahl in Gebieten mit Japan-Käfer-Befall zu verwenden.

Resumen. Los escarabajos japoneses adultos de Popillia japonica son una de las principales plagas de rosas cultivadas que causan daños extensos por alimentación en follaje y flores. Los insecticidas son primariamente utilizados para minimizar los daños a las rosas; sin embargo, podrían perjudicar a los enemigos naturales y su uso puede estar restringido, particularmente en jardines públicos. Una estrategia de manejo alternativo es el uso de genotipos de rosa que sean tolerantes o menos susceptibles al escarabajo. Este estudio evaluó la susceptibilidad de tres nuevos genotipos de rosa introducidos en el Jardín Crasberg en el Jardín Botánico de Chicago, Glencoe, IL. Los genotipos fueron Rosa 'Radrazz' Knock Out ${ }^{\mathrm{TM}}$, Rosa 'Crimson Bouquet' y Rosa 'Love and Peace.' Dos experimentos de laboratorio se llevaron a cabo en 2002 y 2003 para evaluar la susceptibilidad de los nuevos genotipos al ataque del escarabajo japonés. A pesar de que hubo diferencias estadísticas significativas entre los genotipos, en casi todos los casos, el daño medio excedió el 50\%. Las tasas de daño para los experimentos de 2002 y 2003 estuvieron entre 15 a $78 \%$ y 60 a $75 \%$, respectivamente. Para los experimentos múltiples variaron de 34 a $58 \%$ y 47 a $53 \%$, respectivamente. Estos resultados indican que todos los genotipos de rosas son susceptibles al escarabajo japonés y pueden no ser selecciones apropiadas para uso en áreas con poblaciones de aquel ya establecidas. 